\title{
CCDC26 Gene
}

National Cancer Institute

\section{Source}

National Cancer Institute. CCDC26 Gene. NCI Thesaurus. Code C134628.

This gene may be involved in the modulation of cellular responses to retinoic acid. 